Journal of Sustainable Development of Transport and Logistics

journal home page: https://jsdtl.sciview.net

Savchenko, L., Zhigula, S., Yurchenko, K., Vovk, Y., \& Oleksiuk, A. (2021). Combination of different means of parcel deliveries in urban logistics in adverse weather conditions. Journal of Sustainable Development of Transport and Logistics, 6(1), 6-17. doi:10.14254/jsdtl.2020.5-2.1.

\title{
Combination of different means of parcel deliveries in urban logistics in adverse weather conditions
}

\author{
Lidiia Savchenko *D, Sophia Zhigula *, Kate Yurchenko *, \\ Yuriy Vovk**iD, Andrii Oleksiuk** \\ ${ }^{*}$ National Aviation University, \\ 1, Liubomyra Huzara ave., Kyiv, 03058 Ukraine \\ Faculty of Transport, Management and Logistics, Department of Logistics \\ lidiia.savchenko@npp.nau.edu.ua; 5704770@stud.nau.edu.ua; kyurchenko2001@gmail.com \\ ${ }^{* *}$ Ternopil Ivan Puluj National Technical University, \\ 56 Ruska str., 46001 Ternopil, Ukraine \\ Department of Automobiles \\ vovkyuriy@ukr.net; octavian1100@ukr.net
}

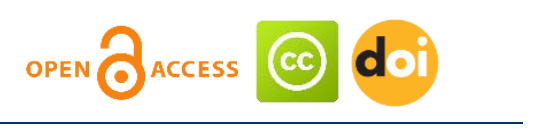

Article history:

Received: November 05, 2020

1st Revision: November 25,

2020

Accepted: December 28,

2020

DOI:

10.14254/jsdtl.2021.6-1.1
Abstract: Purpose. The main purpose of the article is to assess the economic and socio-environmental costs of the urban delivery of small shipments in difficult weather conditions with a combination of different delivery means - a car, a motorcycle, a bicycle and a pedestrian courier.

Methodology. The methodology for determining the integrated costs of urban logistics for small shipments in difficult weather conditions is based on an assessment of the region's synoptic data, statistics on road accidents and congestion levels, as well as on the specific operating conditions of the delivery company.

Results. The result of the work is the cost of combining allseason delivery means with a motorcycle and a bicycle, which can only be used under favorable weather conditions.

The theoretical contribution. The theoretical contribution consists in the presentation of a methodology that makes it possible to estimate the complex costs of a combination of various urban delivery means.

Practical implications. Practical implementation consists in calculating the total costs for the delivery of goods for an online store in Kyiv with various combinations of delivery means, which allows to choose the most successful alternative.

Keywords: city logistics, parcel delivery, bad weather conditions, internal and external costs, commination of different means of delivery. 


\section{Introduction}

Nowadays urban logistics is becoming more and more popular. This may occur due to different reasons, but one of the most important is the growth of e-commerce. E-commerce-related last-mile logistics have a great impact on cities. Recent years have seen sustained growth in e-commerce in most developed countries, a trend that has only been reinforced by the COVID-19 pandemic. But at the same time there are great negative environmental impacts from urban freight transportation to a large extent are derived from the fact that conventionally fuelled vehicles are mainly used for transporting goods. Many countries have implemented regulations aimed at setting high technical parameters for conventionally fueled vehicles in order to reduce their negative impacts, however, in the long term these seem to be insufficient. This, combined with the issue of oil resources depletion, leads to the need to search for alternative forms of delivery transport.

According to (Gevaersa at al., 2014) the last mile is currently regarded as one of the more expensive, least efficient and most polluting sections of the entire logistics chain. The last mile, described as the last stretch of a parcel delivery to the final consignee who has to take reception of the goods at home or at a cluster / collection point or at the office, accounts depending on several characteristics, for $13 \%$ up to $75 \%$ of the total supply chain costs. Related to these high costs are the many inefficiencies in the last mile and the poor environmental performance. Currently, cars and vehicles are dominated as means of urban delivery which generates significant negative effects on the urban environment and directly affect the health of city inhabitants. In view of the growing significance of the issues connected with saving energy resources and promoting environmentally friendly transport systems, solutions based on alternative modes and sources of energy are becoming more and more important. And one of such solutions is usage bicycles, bikes and on-foot courier as alternative delivery modes.

\section{Literature review}

Urban goods transport is a fundamental component of actual city life. Every day, people consume and use goods of very different types and dimensions (e.g., food, clothes, furniture, books, cars and computers) produced throughout the world. Furthermore, freight transport maintains a set of core relationships within urban areas since a city is an entity where production, distribution and consumption activities are located and use limited land. Moreover, the number of people, who live in cities, grows each year. The reasons for the complication of urban logistics:

1. Today, $55 \%$ of the world's population lives in urban areas, a proportion that is expected to increase to 68\% by 2050 (World Urbanization Prospects, 2019).

2. Till the 2014 more than 100 million people have migrated to cities globally since 2000 (World urbanization prospects, 2014).

3. By 2050, at least $70 \%$ of the world population will live in cities (World urbanization prospects, 2014).

4. In Europe, around 75\% of the population lives in urban areas (Degree of urbanization, 2020).

5. Inventories of the Intergovernmental Panel on Climate Change (IPCC) emission quantification methodology, and the creation of scenarios for up to 10 subsequent years, it is possible to verify that individual motorized transport accounts for $60 \%$ of the total emissions from the urban transportation sector (Toledo \& Rovere, 2018).

6. Urban freight vehicles account for $6-18 \%$ of total urban travel (Study on Urban Freight Transport, 2012) and 19\% of energy use and 21\% of CO2 emissions in Europe (Russo \& Comi, 2012).

7. Annually, approximately $1 \%$ of the Gross Domestic Product of the European economy is lost due to congestion (Haubold, 2016).

According to Pojani and Stead (Pojani \& Stead, 2015) cities in developing countries are confronted with a rapid growth in transport-related challenges such as pollution, congestion, accidents, public transport decline, energy deletion and environmental degradation. It necessitated the need for sustainable mobility which sought to ensure the mobility by reorienting transport demand towards safe and more environmentally friendly modes of transport (UNECE Handbook on Sustainable Transport and Urban Planning, 2019, Buhari, 2020, Gambetta \& Baric, 2020). 
For example, (Tulu at al., 2019) shows the successful experience of expanding the cycling infrastructure, which saves money for the family budget, almost does not participate in the formation of traffic congestion, and has a beneficial effect on the level of urban air quality.

Model for sustainable urban mobility is expected to cover bus rapid transport, light rail, tram, electrification, cycling and walking. Furthermore, some of the essential benefits of adopting sustainable urban mobility to solve the challenges of our increasing urbanization and motorization include the following:

1. Reduction in road congestion.

2. Reduction in travel/journey time.

3. Promotion of safe and convenient means for movement.

4. Reduction in pollution and improved healthier environment.

5. Facilitation of intermodal transport system (Buhari, 2020).

In the urban distribution of goods, the road mode appears to be dominant in urban mobility. However, this trend is changing. European cities are moving towards more sustainable, quiet, healthy, cleaner, smoother mobility with low emission levels, as far as the urban distribution of goods is concerned. The innovative city logistics of zero or low $\mathrm{CO} 2$ emissions can contribute to this goal, particularly in dense urban areas where freight journeys are mostly short.

With the global focus on the environmental aspect, transportation companies in urban areas have been innovating in the search of alternative technologies in the fight against the emission of greenhouse gases and atmospheric pollutants.

So, it is necessary to consider all delivery transport modes to understand situation as a whole, the most popular and commonly used ones are automobile, on-foot, motorcycle and bicycle deliveries.

\section{Research methods}

Consider the features of using various delivery vehicles for urban package delivery:

- car;

- motorcycle;

- bicycle;

- on-foot courier using public transport.

Car

From the above list, a car is the most studied means of transportation in the city, both in terms of direct and external costs. Other delivery vehicles have been studied much less and require aggregation of acquired knowledge.

This is a very convenient type of transportation because you can deliver orders not only to one point, but collect several orders at once and deliver them to a certain area. The weather conditions have almost no influence on the car, it will be able to leave in the rain and snow, without bringing strong discomfort to the courier. On the other hand, this type of delivery also has its drawbacks. First of all, it is a floating price that depends on fuel prices. Moreover, the driver can simply get stuck in a traffic jam and delay. In this, cars are much inferior to other types of delivery.

\section{Motorcycle}

A delivery motorcycle is much more cost-effective than a delivery car. Not only is it cheaper to buy (or hire), but it is also cheaper to run (in terms of fuel costs, insurance and tax), as well as being cheaper to maintain.

Motorcycles make it easier to navigate through congested traffic. While a car would be stopped by the traffic jam, a motorcycle can navigate around the traffic with ease. This makes it more reliable and in turn, more efficient for businesses.

\section{Bicycle}

Cycle logistics have the ability to contribute to a cleaner and smoother environment. In addition, cycle logistics has the ability to overcome many of the negative obstacles to the last part of the delivery. Indeed, smaller vehicles do not need many parcels to reach a higher load factor, they do not take up much space when they park, do not pay to park and even on the street itself, helping to lessen the congestion. 
Thus, a solution that addresses some important concerns in the transportation of goods in urban areas is cargo cycles, such as bicycles, cargo bikes and cargo tricycles, that can be electric powered or not. The existing literature is still weak and very recent in the diffusion of this innovation.

Cargo cycles are a zero-emission alternative to light goods vehicles in city centres. This paper improves our understanding of how to develop cycle logistics to reduce the adverse impacts of urban goods deliveries without reducing the quality of city living.

Overall, studies find that the use of cargo cycles represent a viable solution for urban freight transport.

For example, Lenz and Riehle (2013) suggest that cycle freight can form around $25 \%$ of city center commercial traffic in the medium term and that a potential market does exist. Specific areas of application and markets include courier, express and parcel services and the delivery of basic products in catering, but there is a significant potential for cycle freight to carry out deliveries with small volumes and comparatively low weight (ibid). In terms of decarbonizing the urban logistics sector, a London based case study finds that the total distance travelled and the CO2e emissions per parcel delivered fell by $20 \%$ and $55 \%$ respectively as a result of a delivery system utilizing urban consolidation centers and small electric vehicles and cargo tricycles (Allen et al., 2012), while a Dutch study estimated possible annual fuel savings for the Netherlands of 8,500,000 l of diesel, or 21,000 tons of CO2 (Maes \& Vanelslander, 2012).

\section{On-foot delivery}

On-foot delivery is an attractive, sustainable way to deliver packages in the city. The courier's travel speed is comparable to the speed of a bicycle in congestion-free conditions, since he can use public transport for part of the route, as it proved in (Galkin et al., 2019). Naturally, the most significant limiting factor for a walking courier is the ability to take a small amount of cargo. That is why the on-foot courier is mainly used for package and postal deliveries in the city.

Further calculations are a continuation of the research of Comi and Savchenko, 2020). In the studies of these authors, presented at the conference Green Cities 2020, as well as in (Savchenko \& Donets, 2020, Savchenko, 2020), direct internal and external costs were calculated when using a car, motorcycle, bicycle and on-foot courier in Kyiv. The technique has been tested on an online store that carries out about 100 deliveries per day. For its conditions, the required number of different delivery vehicles is determined (Tab. 1), as well as all components of internal and external costs for urban logistics (Table 2 and 3 ).

\section{Table 1: Parameters of delivery tour/route along the working shifts}

\begin{tabular}{|c|c|c|c|c|c|c|c|c|c|}
\hline \multirow{2}{*}{ Route Parameter } & \multirow{2}{*}{ Unit } & \multicolumn{4}{|c|}{ 1st shift } & \multicolumn{4}{|c|}{ 2nd shift } \\
\hline & & car & moto & bicycle & foot & car & moto & bicycle & foot \\
\hline Limitation for cargo capacity & unit & 133 & 20 & 10 & 6 & 133 & 20 & 10 & 6 \\
\hline Speed & $\mathrm{km} / \mathrm{h}$ & 30.21 & 36.77 & 14.27 & 15.10 & 28.10 & 36.07 & 14.11 & 14.05 \\
\hline $\begin{array}{l}\text { Number of customers on the } \\
\text { route }\end{array}$ & clients & 30.00 & 20.00 & 10.00 & 6.00 & 30.00 & 20.00 & 10.00 & 6.00 \\
\hline $\begin{array}{l}\text { Maximal number } \\
\text { tours/routes per shift }\end{array}$ & unit & 1.01 & 1.49 & 1.98 & 2.74 & 1.00 & 1.49 & 1.98 & 2.72 \\
\hline $\begin{array}{l}\text { Required routes per shift } \\
\text { Number of means needed for }\end{array}$ & unit & 3.33 & 5.00 & 10.00 & 16.67 & 3.33 & 5.00 & 10.00 & 16.67 \\
\hline daily delivery & veh. & 1.67 & 2.50 & 5.00 & 8.33 & 1.67 & 2.50 & 5.00 & 8.33 \\
\hline
\end{tabular}

Source: Comi \& Savchenko, 2020 


\begin{tabular}{|c|c|c|c|c|c|c|c|c|}
\hline \multirow[b]{2}{*}{$\begin{array}{l}\text { Delivery } \\
\text { Mode }\end{array}$} & \multicolumn{7}{|c|}{ Components of Internal Costs [EUR/day] } & \multirow{2}{*}{$\begin{array}{c}\text { Total } \\
\text { Annual } \\
\text { Internal } \\
\text { Costs for } 1 \\
\text { Means } \\
\text { [EUR/year] }\end{array}$} \\
\hline & Salary & Amortization & $\begin{array}{l}\text { Cost of } \\
\text { fuel }\end{array}$ & $\begin{array}{l}\text { Maintenance } \\
\text { and Repair }\end{array}$ & $\begin{array}{c}\text { Other } \\
\text { Operating } \\
\text { Expenses }\end{array}$ & $\begin{array}{c}\text { Other } \\
\text { Expenses }\end{array}$ & $\begin{array}{c}\text { Total } \\
\text { Internal } \\
\text { Costs }\end{array}$ & \\
\hline Car & 133,33 & 41,67 & 354,06 & 2,78 & 1,39 & 26,66 & 559,89 & 61186 \\
\hline Motorbike & 200,00 & 16,67 & 239,11 & 1,67 & 0,83 & 22,91 & 481,19 & 35127 \\
\hline Bicycle & 300,00 & 4,17 & - & 1,67 & 0,83 & 15,33 & 322,00 & 11753 \\
\hline $\begin{array}{l}\text { On foot / } \\
\text { Transit }\end{array}$ & 416,67 & - & - & - & - & 20,83 & 437,50 & 9585 \\
\hline
\end{tabular}

Source: Comi \& Savchenko, 2020

Table 3: Annual external cost for various types of urban delivery modes

\begin{tabular}{lccc} 
& \multicolumn{3}{c}{ Annual external cost, euro } \\
\cline { 2 - 4 } Delivery mode & Accident & Congestion & Pollution \\
\hline Car & 506 & 9264 & 250 \\
Motorcycle & 64938 & 3111 & 413 \\
Bicycle & 12747 & 1235 & 0 \\
On-foot & 497 & 0 & 0 \\
\hline
\end{tabular}

Source: Comi \& Savchenko, 2020

Consequently, we can see that the highest rating has on-foot delivery, but it cannot be multifunctional, this delivery mode has a great influence from the human forces and responsibilities. The second one in this rating is bicycle, it is a good solution for delivery services especially in warm days, also it is a fully environmentally-friendly mode of transport. Cars as a delivery mode of transport is on the third place, it is quite clear, as it has huge costs on its maintenance, it has a great bad impact on the ecology. The last one is motorcycle delivery transport mode, as it is also not so eco-friendly as bicycle or on-foot delivery, it cannot be applicable for delivery under all weather conditions.

\section{Influence of weather conditions on choice of delivery mode of transport}

Unfortunately, the use of bicycles and motorcycles, which have a positive effect on the social and ecological situation in the city, is limited in regions with cold, snowy winters, which include Ukraine and Kyiv in particular. What is more, one of the most important factors in choice of delivery mode of transport is weather.

Let's consider an information about weather conditions and changes during a year in Kyiv (Fig. 1-3).

Figure 1: Average temperature of the year

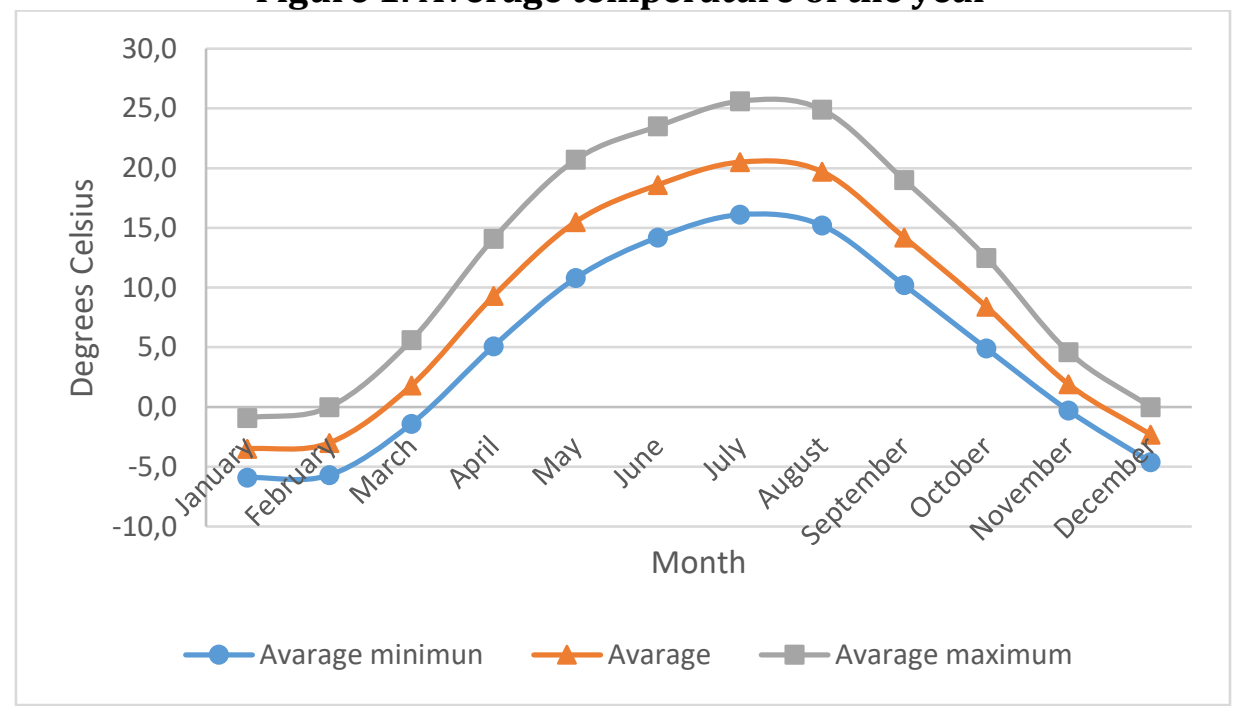

Source: based on (Climate in Kyiv) 
Figure 2: Number of downfalls every month per year

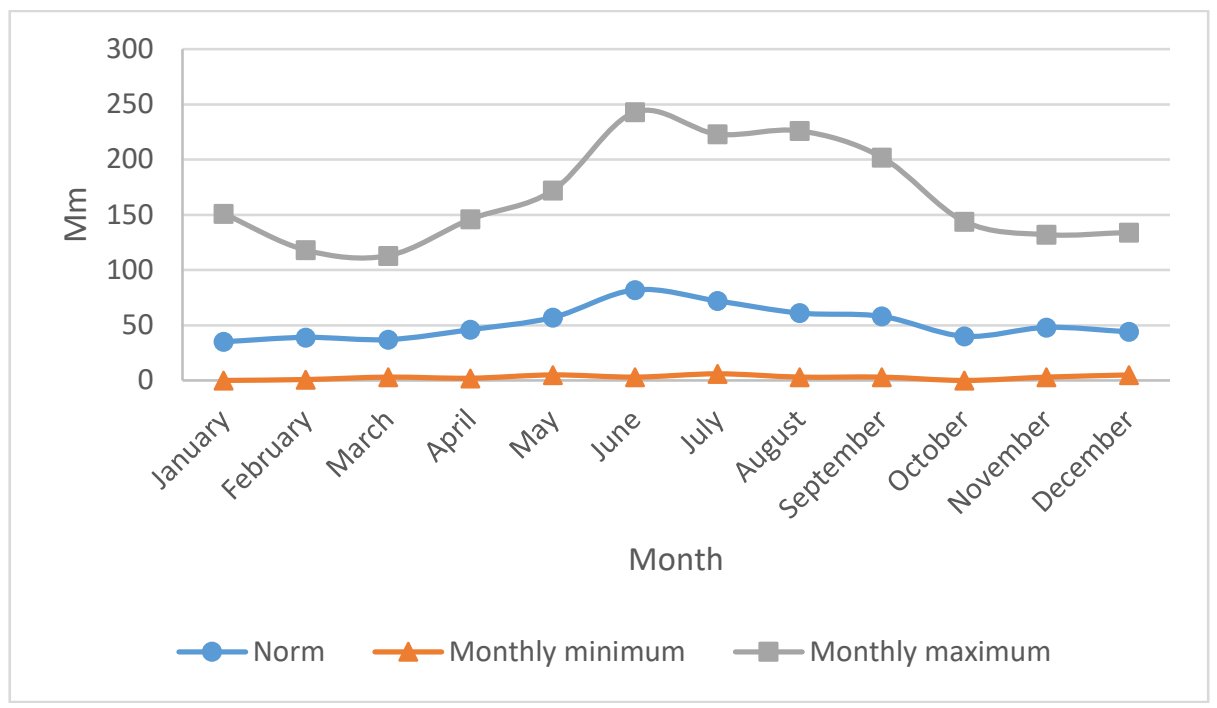

Source: based on (Climate in Kyiv)

Figure 3: Average volume of precipitation per year

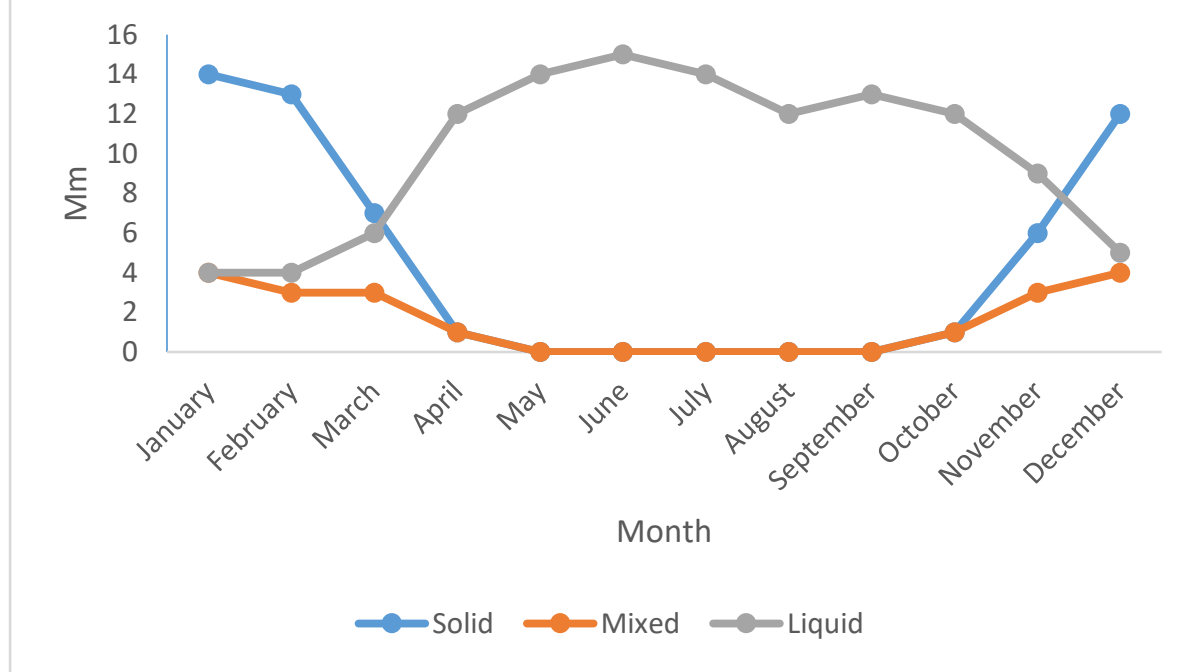

Source: based on (Climate in Kyiv)

Here we can see that situation with downfalls, especially snow makes it more difficult for bicycles and motorcycles to be competitive in terms of fast and safe delivery. So, there is a need to calculate costs, which are related to different modes of transport in order to be able to make a decision about rational combination of different delivery modes for transportation through all seasons.

\section{Costs calculation for season with difficult weather conditions}

Based on the analysis of Fig. 1-3, the number of days per year was determined, during which each type of city delivery can be used. Tab. 4 indicates the months in which not all means can be used.

\section{Table 4: Average number of working days for season with difficult weather conditions}

\begin{tabular}{lccccc} 
& \multicolumn{5}{c}{ Number of Days } \\
\cline { 2 - 5 } Delivery mode & January & February & March & November & December \\
\hline Car & 31 & 28 & 31 & 30 & 31 \\
Motorcycle & 0 & 0 & 15 & 16 & 0 \\
Bicycle & 0 & 0 & 10 & 9 & 0 \\
On-foot/transit & 31 & 28 & 31 & 30 & 31 \\
\hline
\end{tabular}

Firstly, it is necessary to determine the internal and external costs in order to calculate the total ones. 
Considering that a car and an on-foot courier can be used for city delivery throughout the entire calendar year, the authors have assessed the possibility and feasibility of combining these "universal" delivery modes with a motorcycle and a bicycle during the warmer months. Thus, the following combinations were evaluated:

1) car - motorcycle;

2) car - bicycle;

3) on-foot courier - motorcycle;

4) on-foot courier - bicycle.

Table 5 shows numbers of working day for each combination.

Table 5: Numbers of working day for each combination of city delivery modes for season with difficult weather conditions

\begin{tabular}{lccccc} 
& \multicolumn{5}{c}{ Working days } \\
\cline { 2 - 6 } Delivery mode & January & February & March & November & December \\
\hline $1^{\text {st }}$ combination & & & & & \\
\hline Car & 31 & 28 & 16 & 14 & 31 \\
Motorcycle & 0 & 0 & 15 & 16 & 0 \\
\hline $\mathbf{2}^{\text {nd }}$ combination & & & & 21 & 31 \\
\hline Car & 31 & 28 & 21 & 9 & 0 \\
Bicycle & 0 & 0 & 10 & 21 & 31 \\
\hline $\mathbf{3}^{\text {rd }}$ combination & 31 & 28 & 21 & 9 & 0 \\
\hline On-foot & 0 & 0 & 10 & 14 & 0 \\
Bicycle & & & & 16 & \\
\hline $\mathbf{4}^{\text {th }}$ combination & 31 & 28 & 16 & & \\
\hline On-foot & 0 & 0 & 15 & & \\
Motorcycle & & & &
\end{tabular}

Table 6-9 shows internal costs for each combination.

Table 6: Internal costs of combination "Car+Motorcycle" for season with difficult weather conditions

\begin{tabular}{|c|c|c|c|c|c|c|}
\hline \multirow{2}{*}{ Delivery mode } & \multirow{2}{*}{ Salary costs per day } & \multirow{2}{*}{\multicolumn{5}{|c|}{$\begin{array}{l}\text { March } \\
\text { Salary }\end{array}$}} \\
\hline & & & & & & \\
\hline Car & 133,33 & 4133,23 & 3733,24 & 2133,28 & 1866,62 & 4133,23 \\
\hline Motorcycle & 200 & 0 & 0 & 3000 & 3200 & 0 \\
\hline Delivery mode & $\begin{array}{c}\text { Amortization costs per } \\
\text { day }\end{array}$ & \multicolumn{5}{|c|}{ Amortization } \\
\hline Car & 41,67 & 1291,77 & 1166,76 & 666,72 & 583,38 & 1291,77 \\
\hline Motorcycle & 16,67 & 0,00 & 466,76 & 266,72 & 233,38 & 516,77 \\
\hline Delivery mode & Cost on fuel per day & \multicolumn{5}{|c|}{ Fuel } \\
\hline Car & 354,06 & 10975,86 & 9913,68 & 5664,96 & 4956,84 & 10975,86 \\
\hline Motorcycle & 239,11 & 0,00 & 0,00 & 3586,65 & 3825,76 & 0,00 \\
\hline Delivery mode & $\begin{array}{c}\text { Maintenance and Repair } \\
\text { costs per day }\end{array}$ & \multicolumn{5}{|c|}{ Maintenance and Repair } \\
\hline Car & 2,78 & 86,18 & 77,84 & 44,48 & 38,92 & 86,18 \\
\hline Motorcycle & 1,67 & 0 & 0 & 25,05 & 26,72 & 0 \\
\hline Delivery mode & Other expenses per day & \multicolumn{5}{|c|}{ Other expenses } \\
\hline Car & 26,66 & 826,46 & 746,48 & 426,56 & 373,24 & 826,46 \\
\hline Motorcycle & 22,91 & 0 & 0 & 343,65 & 366,56 & 0 \\
\hline
\end{tabular}




\begin{tabular}{|c|c|c|c|c|c|c|}
\hline \multirow{2}{*}{ Delivery mode } & \multirow{2}{*}{ Salary costs per day } & January & February & March & November & December \\
\hline & & \multicolumn{5}{|c|}{ Salary } \\
\hline Car & 133,33 & 4133,23 & 3733,24 & 2799,93 & 2799,93 & 4133,23 \\
\hline Bicycle & 417 & 0 & 0 & 4166,7 & 3750,03 & 0 \\
\hline Delivery mode & Amortization costs per day & \multicolumn{5}{|c|}{ Amortization } \\
\hline Car & 41,67 & 1291,77 & 1166,76 & 875,07 & 875,07 & 1291,77 \\
\hline Bicycle & 4,17 & 0,00 & 0,00 & 41,70 & 37,53 & 0,00 \\
\hline Delivery mode & Cost on fuel per day & \multicolumn{5}{|c|}{ Fuel } \\
\hline Car & 354,06 & 10975,86 & 9913,68 & 7435,26 & 7435,26 & 10975,86 \\
\hline Bicycle & 0 & 0,00 & 0,00 & 0,00 & 0,00 & 0,00 \\
\hline Delivery mode & $\begin{array}{c}\text { Maintenance and Repair } \\
\text { costs per day }\end{array}$ & \multicolumn{5}{|c|}{ Maintenance and Repair } \\
\hline Car & 2,78 & 86,18 & 77,84 & 58,38 & 58,38 & 86,18 \\
\hline Bicycle & 1,67 & 0 & 0 & 16,7 & 15,03 & 0 \\
\hline Delivery mode & Other expenses per day & \multicolumn{5}{|c|}{$\begin{array}{l}\text { Other expenses } \\
\end{array}$} \\
\hline Car & 26,66 & 826,46 & 746,48 & 559,86 & 559,86 & 826,46 \\
\hline Bicycle & 23,74 & 0 & 0 & 237,4 & 213,66 & 0 \\
\hline
\end{tabular}

\begin{tabular}{|c|c|c|c|c|c|c|}
\hline \multirow{2}{*}{ Delivery mode } & \multirow{2}{*}{ Salary costs per day } & \multirow{2}{*}{\multicolumn{5}{|c|}{ Salary }} \\
\hline & & & & & & \\
\hline On-foot & 416,67 & 12916,77 & 11666,76 & 8750,07 & 8750,07 & 12916,77 \\
\hline Bicycle & 417 & 0 & 0 & 4166,7 & 3750,03 & 0 \\
\hline Delivery mode & Amortization costs per day & \multicolumn{5}{|c|}{ Amortization } \\
\hline On-foot & 0,00 & 0,00 & 0,00 & 0,00 & 0,00 & 0,00 \\
\hline Bicycle & 4,17 & 0,00 & 0,00 & 41,70 & 37,53 & 0,00 \\
\hline Delivery mode & Cost on fuel per day & \multicolumn{5}{|c|}{ Fuel } \\
\hline On-foot & 0,00 & 0,00 & 0,00 & 0,00 & 0,00 & 0,00 \\
\hline Bicycle & 0 & 0,00 & 0,00 & 0,00 & 0,00 & 0,00 \\
\hline
\end{tabular}

\begin{tabular}{lcccccc}
\hline Delivery mode & $\begin{array}{c}\text { Maintenance and Repair } \\
\text { costs per day }\end{array}$ & \multicolumn{5}{c}{ Maintenance and Repair } \\
\hline On-foot & 0,00 & 0 & 0 & 0 & 0 & 0 \\
Bicycle & 1,67 & 0 & 0 & 16,7 & 15,03 & 0 \\
\hline Delivery mode & Other expenses per day & \multicolumn{5}{c}{ Other expenses } \\
\hline On-foot & 20,83 & 645,73 & 583,24 & 437,43 & 437,43 & 645,73 \\
Bicycle & 23,74 & 0 & 0 & 237,4 & 213,66 & 0 \\
\hline
\end{tabular}

\begin{tabular}{|c|c|c|c|c|c|c|}
\hline \multirow[b]{2}{*}{ Delivery mode } & \multirow[b]{2}{*}{ Salary costs per day } & January & February & March & November & December \\
\hline & & \multicolumn{5}{|c|}{ Salary } \\
\hline On-foot & 416,67 & 12916,77 & 11666,76 & 6666,72 & 5833,38 & 12916,77 \\
\hline Motorcycle & 200 & 0 & 0 & 3000 & 3200 & 0 \\
\hline Delivery mode & Amortization costs per day & \multicolumn{5}{|c|}{ Amortization } \\
\hline On-foot & 0,00 & 0,00 & 0,00 & 0,00 & 0,00 & 0,00 \\
\hline Motorcycle & 16,67 & 0,00 & 0,00 & 250,05 & 266,72 & 0,00 \\
\hline Delivery mode & Cost on fuel per day & \multicolumn{5}{|c|}{ Fuel } \\
\hline On-foot & 0,00 & 0,00 & 0,00 & 0,00 & 0,00 & 0,00 \\
\hline Motorcycle & 239,11 & 0,00 & 0,00 & 3586,65 & 3825,76 & 0,00 \\
\hline Delivery mode & $\begin{array}{l}\text { Maintenance and Repair } \\
\text { costs per day }\end{array}$ & \multicolumn{5}{|c|}{ Maintenance and Repair } \\
\hline On-foot & 0,00 & 0 & 0 & 0 & 0 & 0 \\
\hline Motorcycle & 1,67 & 0 & 0 & 25,05 & 26,72 & 0 \\
\hline Delivery mode & Other expenses per day & \multicolumn{5}{|c|}{ Other expenses } \\
\hline On-foot & 20,83 & 645,73 & 583,24 & 333,28 & 291,62 & 645,73 \\
\hline Motorcycle & 22,91 & 0 & 0 & 343,65 & 366,56 & 0 \\
\hline
\end{tabular}

Table 10-13 shows external costs for each combination. 


\begin{tabular}{|c|c|c|c|c|c|c|}
\hline & & January & February & March & November & December \\
\hline Delivery mode & Pollution costs per day & \multicolumn{5}{|c|}{ Pollution } \\
\hline Car & 2,3 & 70,9 & 64,1 & 36,6 & 32,0 & 70,9 \\
\hline Motorcycle & 5,7 & 0,0 & 0,0 & 84,9 & 90,5 & 0,0 \\
\hline Delivery mode & Congestion costs per day & \multicolumn{5}{|c|}{ Congestion } \\
\hline Car & 84,8 & 2627,9 & 2373,6 & 1356,4 & 1186,8 & 2627,9 \\
\hline Motorcycle & 42,6 & 0,0 & 0,0 & 639,2 & 681,9 & 0,0 \\
\hline Delivery mode & Accidents costs per day & \multicolumn{5}{|c|}{ Accidents } \\
\hline Car & 4,6 & 143,5 & 129,6 & 74,1 & 64,8 & 143,5 \\
\hline Motorcycle & 889,6 & 0,0 & 0,0 & 13343,4 & 14233,0 & 0,0 \\
\hline
\end{tabular}

\begin{tabular}{|c|c|c|c|c|c|c|}
\hline \multirow[b]{2}{*}{ Delivery mode } & \multirow[b]{2}{*}{ Pollution costs per day } & January & February & March & November & December \\
\hline & & \multicolumn{5}{|c|}{ Pollution } \\
\hline Car & 2,29 & 70,92 & 64,05 & 48,04 & 48,04 & 70,92 \\
\hline Bicycle & 0,00 & 0,00 & 0,00 & 0,00 & 0,00 & 0,00 \\
\hline Delivery mode & Congestion costs per day & \multicolumn{5}{|c|}{ Congestion } \\
\hline Car & 84,77 & 2627,93 & 2373,61 & 1780,21 & 1780,21 & 2627,93 \\
\hline Bicycle & 33,84 & 0,00 & 0,00 & 338,36 & 304,52 & 0,00 \\
\hline Delivery mode & Accidents costs per day & \multicolumn{5}{|c|}{ Accidents } \\
\hline Car & 4,63 & 143,54 & 129,65 & 97,24 & 97,24 & 143,54 \\
\hline Bicycle & 349,23 & 0,00 & 0,00 & 3492,33 & 3143,10 & 0,00 \\
\hline
\end{tabular}

Table 12: External costs of combination "On-foot+Motorcycle" for season with difficult weather conditions

\begin{tabular}{lcccccc} 
& & January & February & March & November & December \\
\cline { 2 - 7 } Delivery mode & Pollution costs per day & \multicolumn{5}{c}{ Pollution } \\
\hline On-foot & 0,00 & 0,00 & 0,00 & 0,00 & 0,00 & 0,00 \\
Motorcycle & 5,66 & 0,00 & 0,00 & 84,86 & 90,52 & 0,00 \\
\hline Delivery mode & Congestion costs per day & & \multicolumn{5}{c}{ Congestion } & 0,00 \\
\hline On-foot & 0,00 & 0,00 & 0,00 & 0,00 & 0,00 & 0,00 \\
Motorcycle & 42,62 & 0,00 & 0,00 & 639,25 & 681,86 & \\
\hline Delivery mode & Accidents costs per day & & & Accidents & & \\
\hline On-foot & 22,68 & 703,23 & 635,18 & 362,96 & 317,59 & 703,23 \\
Motorcycle & 889,56 & 0,00 & 0,00 & 13343,42 & 14232,99 & 0,00 \\
\hline
\end{tabular}

\section{Table 13: External costs of combination "On-foot+Bicycle" for season with difficult weather conditions}

\begin{tabular}{lcccccc} 
& & January & February & March & November & December \\
\cline { 3 - 7 } Delivery mode & Pollution costs per day & & \multicolumn{5}{c}{ Pollution } & \\
\hline On-foot & 0,00 & 0,00 & 0,00 & 0,00 & 0,00 & 0,00 \\
Bicycle & 0,00 & 0,00 & 0,00 & 0,00 & 0,00 & 0,00 \\
\hline Delivery mode & Congestion costs per day & \multicolumn{5}{c}{ Congestion } \\
\hline On-foot & 0,00 & 0,00 & 0,00 & 0,00 & 0,00 & 0,00 \\
Bicycle & 33,84 & 0,00 & 0,00 & 338,36 & 304,52 & 0,00 \\
\hline Delivery mode & Accidents costs per day & & & Accidents & \\
\hline On-foot & 22,68 & 703,23 & 635,18 & 476,38 & 476,38 & 703,23 \\
Bicycle & 349,23 & 0,00 & 0,00 & 3492,33 & 3143,10 & 0,00 \\
\hline
\end{tabular}

In order to evaluate the total costs of the various cost components, it is necessary to calculate the sum for each of the four types of combinations. 


\section{Research results and discussion}

The results of calculating the costs of various combinations of urban delivery modes are presented in Fig. 4.

Figure 4: Internal, external and total costs of various combinations of urban delivery modes

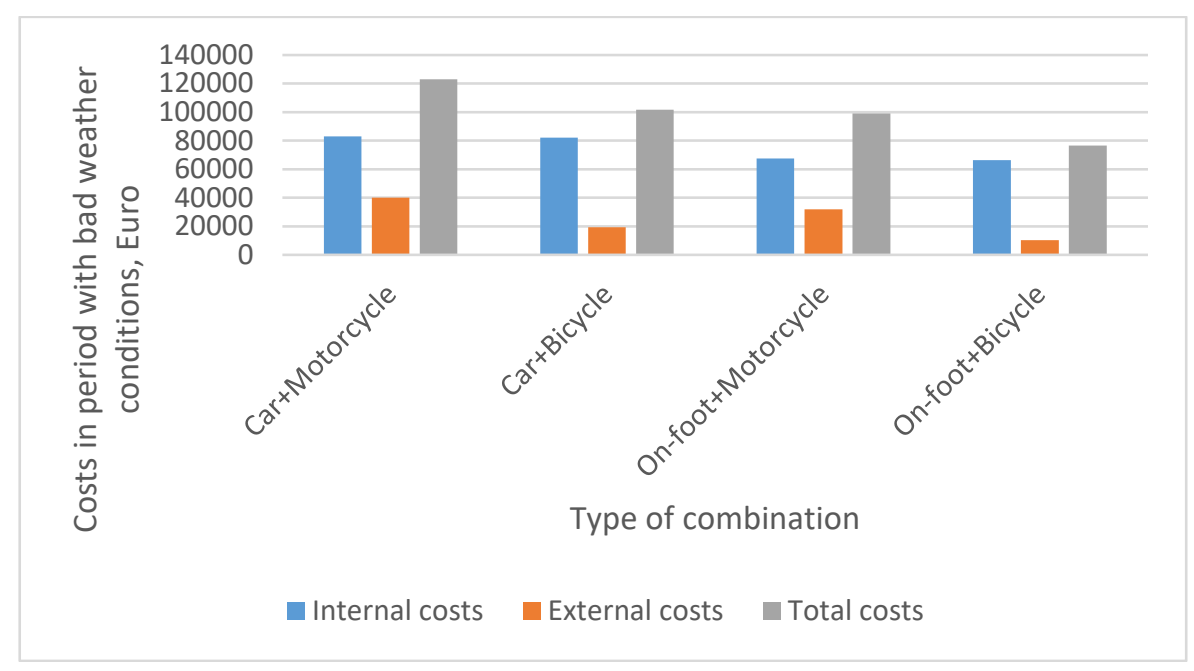

In addition, a rating of various combinations ( 1 - excellent, 4 - poor) was obtained for internal, external and general urban delivery costs (Tab. 14).

\begin{tabular}{lccc}
$\begin{array}{l}\text { Table 14: Rating of internal, external and total costs of different combination of means of urban delivery in } \\
\text { bad weather conditions }\end{array}$ & Internal costs rating & External costs rating & Total costs rating \\
\hline Delivery mode & 4 & 4 & 4 \\
\hline Car+Motorcycle & 3 & 2 & 3 \\
Car+Bicycle & 2 & 3 & 2 \\
On-foot+Motorcycle & 1 & 1 & 1 \\
On-foot+Bicycle & & & \\
\hline
\end{tabular}

The best combination according to all components of the total cost is "On-foot+Bicycle". Such alternative shows the lowest direct cost for urban delivery and is the most environmentally friendly.

It should be added that the results were obtained for specific conditions and cannot be applied to any urban delivery situation. However, the technique outlined in the article allows one to obtain cost estimates for a specific case.

\section{Conclusions}

So, there is a necessity to use collaborative means of urban delivery during the year. It is impossible to use bicycle or motorcycle for the whole year, as it is quite uncomfortable and unsuitable for the bad weather conditions, while these modes of delivery are eco-friendly and economical. The combination of different transport modes is applicable as the solution of this issue.

It is much more profitable for logistics companies or shippers to use a combination of delivery models, rather than preferring anyone. While the courier delivers the order within walking distance, the motorcycle will already be able to deliver several orders. As discussed earlier, bicycles and motorcycles have their drawbacks, namely that amortization must be paid during all the year, while these modes are unusable in bad weather conditions, which affects overall costs. Despite the fact that the company cannot use them in bad weather conditions, it can use the car or on-foot delivery, and when the weather improves, may turn to the help of a bicycle or motorcycle.

Therefore, it is needed to be considered that the impact of all types of costs and choose the appropriate option in order to compose the most convenient combination of deliveries to use with the lowest costs. 


\section{Citation information}

Savchenko, L., Zhigula, S., Yurchenko, K., Vovk, Y., \& Oleksiuk, A. (2021). Combination of different means of parcel deliveries in urban logistics in adverse weather conditions. Journal of Sustainable Development of Transport and Logistics, 6(1), 6-17. doi:10.14254/jsdtl.2020.5-2.1

\section{References}

Allen, J., Browne, M., Woodburn, A., \& Leonardi, J. (2012). The role of urban consolidation centres in sustainable freight transport. Transport Reviews, 32(4), 473-490. https://doi.org/10.1080/01441647.2012.688074.

Buhari, S. O. (2020). Sustainable urban mobility: An approach to urbanization and motorization challenges in Nigeria, a case of Lagos state. Journal of Sustainable Development of Transport and Logistics, 5(2), 90-97. https://doi.org/10.14254/jsdtl.2020.5-2.8.

Buhari, S. O., Aponjolosun, M. O., Oni, B. G., \& Sam, M. W. (2020). Sustainable urban mobility: An approach to urbanization and motorization challenges in Nigeria, a case of Lagos state. Journal of Sustainable Development of Transport and Logistics, 5(2), 90-97. https://doi.org/10.14254/jsdtl.2020.5-2.8.

Climate in Kyiv. (n.d.). Retrieved October 28, 2020 from http://www.pogodaiklimat.ru/climate/33345.htm.

Comi, A., \& Savchenko, L. (2020). Analysis of environment-friendly transport for last-mile logistics. Retrieved from http://greencities-conf.eu/poster-sesions-green-cities-2020/.

Degree of urbanization (percentage of urban population in total population) by continent in 2020 . (2020). Statista. Retrieved from https://www.statista.com/statistics/270860/urbanization-bycontinent/.

Galkin, A., Schlosser, T., Galkina, O., Hodáková, D., \& Cápayová, S. (2019). Investigating using urban public transport for freight deliveries. Transportation Research Procedia, 39, 64-73. http://doi.org/10.1016/j.trpro.2019.06.008.

Gambetta, R., \& Baric, D. (2020). Mobility market transformation - how mobility as a service based on open source principles will impact the ecosystem. Journal of Sustainable Development of Transport and Logistics, 5(2), 22-28. https://doi.org/10.14254/jsdtl.2020.5-2.2.

Gevaersa, R., Voordea, E., \& Vanelslandera, T. (2014). Cost Modelling and Simulation of Last-mile Characteristics in an Innovative B2C Supply Chain Environment with Implications on Urban Areas and Cities. Social and Behavioral Sciences, 125. https://doi.org/10.1016/j.sbspro.2014.01.1483.

Haubold, H. (2016). Cycling and congestion charges: A winning team forcities. European Cyclists' Federation. Retrieved from https://ecf.com/groups/congestion-charges-and-cycling.

Lenz, B., \& Riehle, E. (2013). Bikes for urban freight? Transportation Research Record. Journal of the Transportation Research Board, 2379, 39-45. https://doi.org/10.3141/2379-05.

Maes, J., \& Vanelslander, T. (2012). The use of bicycle messengers in the logistics chain, concepts further revised. Procedia - Social and behavioral sciences, 39, 409-423. https://doi.org/10.1016/j.sbspro.2012.03.118.

Pojani, D., \& Stead, D. (2015). Sustainable urban transport in the developing world: Beyond megacities. Sustainability, 7(6), 7784-7805. https://doi.org/10.3390/su7067784.

Russo, F., \& Comi, A. (2012). City characteristics and urban goods movements: A way to environmental transportation system in a sustainable city. Procd. Soc. Behv. 39, 61-73. https://doi.org/10.1016/j.sbspro.2012.03.091.

Savchenko, L. V. (2020). Air pollution costs for car and motorcycle. In XX International scientificpractical conference of applicants higher education and young scientists "Flight. Modern problems of science", 29-30. 
Savchenko, L. V., \& Donets, A. G. (2020). Assessment of society general economic losses because of traffic jams in Kyiv. Avtoshliakhovyk Ukrayiny, 2, 8-15. https://doi.org/10.33868/0365-83922020-2-262-8-15.

Study on Urban Freight Transport - Final Report. (2012). European Commission. Retrieved from https://ec.europa.eu/transport/sites/transport/files/themes/urban/studies/doc/2012-04urban-freight-transport.pdf.

Toledo, A.L., \& Rovere, E. L. (2018). Urban Mobility and Greenhouse Gas Emissions: Status, Public Policies, and Scenarios in a Developing Economy City, Natal, Brazil. Sustainability, 10(11). https://doi.org/10.3390/su10113995.

Tulu, G.S., Hadgu, M., \& Tarekegn A. G. (2019). Bicycling in Addis Ababa, Ethiopia: Opportunities and challenges. Journal of Sustainable Development of Transport and Logistics, 4(2), 50-59. https://doi.org/10.14254/jsdtl.2019.4-2.5.

UNECE. (2019). Handbook on Sustainable Transport and Urban Planning. Retrieved from https://thepep.unece.org/sites/default/files/2019-

04/UNECE\%20Handbook\%20on\%20Sustainable\%20Transport\%20and\%20Urban\%20Planning \%20draft\%20April\%202019\%20reduced.pdf.

World urbanization prospects - The 2014 Revision Highlights. (2014). United Nations. Department of Economic and Social Affairs, New York, US.

World Urbanization Prospects - The 2018 Revision. (2019). Retrieved from https://population.un.org/wup/Publications/Files/WUP2018-Report.pdf.

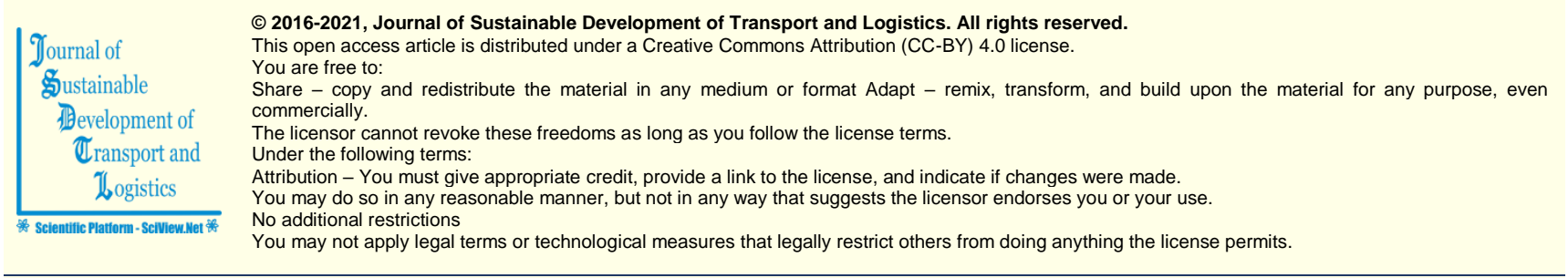

Journal of Sustainable Development of Transport and Logistics (ISSN: 2520-2979) is published by Scientific Publishing House "CSR", Poland, EU and Scientific Publishing House "SciView", Poland, EU

Publishing with JSDTL ensures:

- Immediate, universal access to your article on publication

- High visibility and discoverability via the JSDTL website

- Rapid publication

- Guaranteed legacy preservation of your article

- Discounts and waivers for authors in developing regions

Submit your manuscript to a JSDTL at https://jsdtl.sciview.net/ or submit.jsdt|@sciview.net 